Original Research Paper

\title{
Relationship between Malocclusion and Oral Habits
}

\author{
${ }^{1}$ Davide Giugliano, ${ }^{2}$ Fabriziad'Apuzzo, ${ }^{3}$ Abdolreza Jamilian and ${ }^{4}$ Letizia Perillo \\ ${ }^{1,2,4}$ Department of Medical-Surgical and Dental Specialties, Second University of Naples, Naples, Italy \\ ${ }^{3}$ Department of Orthodontics, Dental Branch, Craniomaxillofacial Research Center, Islamic Azad University, Tehran, Iran
}

\author{
Article history \\ Received: 27-01-2015 \\ Revised: 22-02-2015 \\ Accepted: 07-04-2015 \\ Corresponding Author: \\ Abdolreza Jamilian \\ Department of Orthodontics, \\ Dental Branch, \\ Craniomaxillofacial Research \\ Center, \\ Islamic Azad University, \\ Tehran, Iran \\ E-mail: info@jamilian.net
}

\begin{abstract}
In addition to heredity, oral habits are considered important factors in the etiology of malocclusion. This study was taken to assess the relationship between Malocclusion and Oral Habits. The sample comprised of 674 orthodontically untreated subjects, 324 males (48\%) and 350 females $(52 \%) 12$ to 15 -year-old schoolchildren from the southern part of Italy. Orthodontic variables and oral habits including mouth breathing and swallowing pattern; thumb, finger and lip sucking; and nail biting of the patients were evaluate. Two examiners, who had been previously trained in the use of occlusal indices, screened all the schoolchildren. The chi-square and binomial test was used to evaluate the data. A total of 589 of the subjects were found to have deleterious oral habits. Nail biting was found to be the most common habit $(65.5 \%)$ followed by lip sucking $(42.7 \%)$, mouth breathing (28.6\%), abnormal swallowing pattern $(22.7 \%)$ and thumb sucking (13.2\%). Positive association exist between deleterious oral habits and malocclusions; however, there is no significant relationship between the type of oral habit and malocclusions.
\end{abstract}

Keywords: Malocclusion, Respiration, Tongue Habits, Mouth Breathing/Diagnosis, Deglutition

\section{Introduction}

Malocclusion has a large physical, social and psychological impact on individual and society; (Liu et al., 2009) therefore, epidemiological studies are essential to achieve extensive data for creating public health plans for orthodontic prevention. During the last three decades, a notable increase in orthodontic treatment demand has occurred as a consequence of the high perception rate of malocclusions, along with a greater attention to aesthetics. Many studies have been published on the prevalence of malocclusion and the need for orthodontic treatment in different ethnic groups. Perillo et al. (2010) evaluated the orthodontic features of 12-yearoldschoolchildren in Southern Italy and found a high prevalence rate of crowding and Class I malocclusion. Souames et al. (2006) assessed the orthodontic treatment need in a sample of 9 to 12-year-old French children and reported that the malocclusion status of French schoolchildren was lower than that of European children. Jamilian et al. (2010) observed a relatively lower grades 4 and 5 of orthodontic treatment need for high school students in Middle East.

Oral habits such as finger and thumb sucking, lip sucking, mouth breathing, nail biting (onicofagy) and so on can happen temporarily; however these habits, when excessive or continued, can lead to poor dental health or malocclusion. Lagana et al. (2013) studied the prevalence of malocclusions, oral habits and the need for orthodontic treatment in a sample of 7- to 15-year-old Albanese schoolchildren and stated that oral habits were present in $80.6 \%$ of their subjects. Cavalcanti et al. (2008) also confirmed that there was a positive association between deleterious oral habits and malocclusion. However, Luzzi et al. (2011) reported that no statistically significant associations could be detected between the non-nutritive sucking habits and malocclusion.

The aim of the present epidemiological study was to evaluate the prevalence of malocclusion in 12-year-old schoolchildren in Southern Italy and to verify the association between malocclusions and oral habits.

\section{Subjects and Methods}

The study was carried out in accordance with the ethical standards set forth in the 1964 Declaration of Helsinki. The study target population consisted of schoolchildren attending the second year of secondary school (corresponding to the eighth grade) of statefunded schools in Naples (Southern Italy). Forty-eight schools (13000 pupils) were randomly selected according to a cluster sampling design from an initial 
pool of 79 schools that had been previously identified by the school district to avoid possible biases ensuing from social heterogeneity. Classes within schools were sampled systematically. All students belonging to the sampled classes were examined, both to improve study feasibility and so as not to discriminate among pupils in the same class. Written consent to the examination was obtained from the children and their parents. Sample size was calculated assuming a $50 \%$ prevalence ratio for any characteristics to be estimated and a precision of the estimate of \pm 3 with a $95 \%$ confidence interval (sampling from finite population, Query Advisor, v. 4.0, Statistical Solution Ltd, Cork, Ireland). This assumption leads to the highest sample size with the given precision. Nine hundred and eighty-seven students were randomly selected according to a cluster sampling design.

All selected children present at the schools on the day of the examination (867subjects) participated in the study. Students who had already finished their orthodontic treatment and those who were undergoing treatment at the time of the study were excluded. Therefore, the sample for final analysis comprised only 674 orthodontically untreated subjects.

The students were examined at their schools, in a quiet classroom without external interference, under natural or artificial illumination. The examination lasted approximately $15 \mathrm{~min}$ per child. The assessment of dental occlusion was carried out using latex gloves, dental mouth mirrors and millimetric rulers. No radiographs, study casts, or previous written records were used. Personal data and information about orthodontic treatment were obtained directly from the students. The clinical examination was carried out by two examiners, who had previously undergone calibration to standardize their procedures.

The orthodontic variables and Oral habits evaluated were as follows.

\section{Orthodontic Variables}

Molar relationship: The relationship between the upper and lower first permanent molars was determined according to Angle's classification. Patients with subdivision malocclusions were included in the Class II or Class III groups on the basis of the predominant occlusal characteristic, or according to the relationship between the canines.

Overjet and Overbite: Values between 0 and $4 \mathrm{~mm}$ were considered normal.

Posterior crossbite: A posterior crossbite was diagnosed when there was a crossover of at least one tooth in the posterior segments of the dental arches. A posterior crossbite could be unilateral (right or left) or bilateral.

Scissor bite: A scissor bite was considered to be present when the palatal cusps of the upper molars were positioned buccally in relation to the buccal cusps of the lower molars.
Crowding and diastema: These were recorded for the anterior as well as for the posterior segments. A midlinediastema was considered to be present when there was a space of at least $2 \mathrm{~mm}$ between the maxillary central incisors.

\section{Oral Habits}

Oral habits including mouth breathing and swallowing pattern; thumb, finger and lip sucking; and nail biting of the patients were evaluated. The presence of these oral habits was determined independently by two investigators and further confirmed by questioning. The children were observed when completely relaxed. Each assessment was repeated two or three times until the two examiners reached an agreement. Before the oral habit examinations, the parents answered a questionnaire.

Mouth breathing was diagnosed observing lip incompetence at rest, the tension of the oral muscles while closing the lips and dilated nostrils when it was asked to breathe through the nose.

The swallowing pattern was assessed by a method suggested by Melsen et al. (1987) the evaluation was done while the child was swallowing saliva or small amounts of water. First, the mandibular movements and the perioral muscle contractions were observed during swallowing. A normal swallowing pattern was characterized by tooth contact and activity of the masseter muscle, with little if any use of the perioral muscles. If a muscle contraction was not registered, the swallowing pattern was considered as abnormal. Each swallowing assessment was repeated 3 times and the consensus opinion was accepted thumb and lip sucking along with nail biting were diagnosed by observing fingers, lip and nails to see if there were any signs indicating persistence of sucking or biting. A questionnaire was also used to confirm the findings.

\section{Statistical Methods}

Statistical Package for Social Sciences version 20 (SPSS Inc, Chicago, Illinois, USA) was used for data analysis. The chi-square and binomial test was used to evaluate the data.

\section{Results}

A total of 867 students from 44 secondary schools in Naples were examined. One hundred and ninety three students were excluded because either they had received orthodontic treatment or were currently undergoing orthodontic treatment. The final sample comprised of 674 subjects, 324 males (48\%) and 350 females (52\%) 12 to 15-year-old schoolchildren. From the study population, 282 of the males and 307 of the females had deleterious oral habits. Pearson's Chi-square test showed that there was no relationship between gender and oral habits $(\mathrm{p}<0.791)$ Table 1 . Regarding type of the habit; nail biting $(65.5 \%)$ was most commonly seen followed by lip sucking (42.7\%), mouth breathing (28.6\%), abnormal swallowing pattern (22.7\%) and thumb sucking (13.2\%). 
The prevalence of each malocclusion in the total sample is reported in Table 2. Tables 3 to 7 show the distribution of deleterious oral habits according to the various types of malocclusions. Pearson's Chi-square test showed that there were no relationship between the type of oral habit and malocclusions. However, binomial test showed that there were significant relationships between subjects with deleterious oral habits and malocclusions.

Table 1. Prevalence and distribution of oral habits by gender

\begin{tabular}{|c|c|c|c|c|c|c|c|}
\hline \multirow[b]{3}{*}{ Gender } & \multicolumn{7}{|c|}{ Presence of oral habit } \\
\hline & \multicolumn{2}{|l|}{ Yes } & \multicolumn{2}{|l|}{ No } & \multicolumn{2}{|c|}{ Total } & \multirow[b]{2}{*}{ P-Value } \\
\hline & $\mathrm{N}$ & $\%$ & $\mathrm{~N}$ & $\%$ & $\mathrm{~N}$ & $\%$ & \\
\hline$\overline{\text { Male }}$ & 282 & 41.8 & 42 & 6.2 & 324 & 48.0 & 0.791 \\
\hline Female & 307 & 45.6 & 43 & 6.4 & 350 & 52.0 & \\
\hline Total & 589 & 87.4 & 85 & 12.6 & 674 & 100.0 & - \\
\hline
\end{tabular}

Table 2. Prevalence of malocclusions in the total sample

\begin{tabular}{llccc}
\hline & & Prevalence & & \\
Occlusal variables & & N & \% & 95\% Confidence interval \\
\hline Sagittal variables & CL I Malocclusion & 415 & 61.6 & $57.9-65.3$ \\
& CL II Malocclusion & 237 & 35.2 & $31.4-39.20$ \\
& CL III Malocclusion & 22 & 3.3 & $1.8-4.600$ \\
& Overjet $>4 \mathrm{~mm}$ & 99 & 14.7 & $12.0-17.50$ \\
& Overjet $0-4 \mathrm{~mm}$ & 573 & 85.0 & $82.2-87.70$ \\
& Overjet $<0 \mathrm{~mm}$ & 2 & 0.3 & $0.0-0.700$ \\
Vertical variables & 146 & 21.7 & $18.8-24.80$ \\
& Overbite $>4 \mathrm{~mm}$ & 525 & 77.9 & $74.8-80.7$ \\
Transverse variables & 3 & 0.4 & $0-100000$ \\
& Overbite $0-4 \mathrm{~mm}$ & 83 & 12.3 & $9.9-15.00$ \\
& Overbite $<0 \mathrm{~mm}$ & 18 & 2.7 & $1.6-3.900$ \\
& Unilateral Crossbite & 18 & 2.7 & $1.5-4.000$ \\
\hline
\end{tabular}

Table 3. Prevalence of oral habit according to dental class

\begin{tabular}{|c|c|c|c|c|c|c|c|c|c|c|}
\hline \multirow[b]{2}{*}{$\begin{array}{l}\text { Oral habit } \\
\text { Problem }\end{array}$} & \multicolumn{2}{|c|}{$\begin{array}{l}\text { Mouth } \\
\text { Breathing }\end{array}$} & \multicolumn{2}{|c|}{$\begin{array}{l}\text { Abnormal } \\
\text { Swallowing }\end{array}$} & \multicolumn{2}{|c|}{$\begin{array}{l}\text { Thumb } \\
\text { Sucking }\end{array}$} & \multicolumn{2}{|l|}{$\begin{array}{l}\text { Lip } \\
\text { Sucking }\end{array}$} & \multicolumn{2}{|l|}{$\begin{array}{l}\text { Nail } \\
\text { Biting }\end{array}$} \\
\hline & $\begin{array}{l}\text { Yes } \\
n=193\end{array}$ & $\begin{array}{l}\text { No } \\
\mathrm{n}=481\end{array}$ & $\begin{array}{l}\text { Yes } \\
\mathrm{n}=153\end{array}$ & $\begin{array}{l}\text { No } \\
\mathrm{n}=521\end{array}$ & $\begin{array}{l}\text { Yes } \\
\mathrm{n}=89\end{array}$ & $\begin{array}{l}\text { No } \\
\mathrm{n}=585\end{array}$ & $\begin{array}{l}\text { Yes } \\
\mathrm{n}=288\end{array}$ & $\begin{array}{l}\text { No } \\
\mathrm{n}=386\end{array}$ & $\begin{array}{l}\text { Yes } \\
n=442\end{array}$ & $\begin{array}{l}\text { No } \\
\mathrm{n}=232\end{array}$ \\
\hline CL I Malocclusion & 114 & 301 & 97 & 318 & 56 & 359 & 179 & 236 & 274 & 141 \\
\hline CL II Malocclusion & 74 & 163 & 49 & 188 & 27 & 210 & 102 & 135 & 152 & 85 \\
\hline CL III Malocclusion & 5 & 17 & 7 & 15 & 6 & 16 & 7 & 15 & 16 & 6 \\
\hline$P$ value & 0.490 & & 0.427 & & 0.105 & & 0.575 & & 0.686 & \\
\hline
\end{tabular}

Table 4. Prevalence of oral habit according to overjet

\begin{tabular}{|c|c|c|c|c|c|c|c|c|c|c|}
\hline \multirow[b]{2}{*}{$\begin{array}{l}\text { Oral habit } \\
\text { Problem }\end{array}$} & \multicolumn{2}{|c|}{$\begin{array}{l}\text { Mouth } \\
\text { Breathing }\end{array}$} & \multicolumn{2}{|c|}{$\begin{array}{l}\text { Abnormal } \\
\text { Swallowing }\end{array}$} & \multicolumn{2}{|c|}{$\begin{array}{l}\text { Thumb } \\
\text { Sucking }\end{array}$} & \multicolumn{2}{|l|}{$\begin{array}{l}\text { Lip } \\
\text { Sucking }\end{array}$} & \multicolumn{2}{|l|}{$\begin{array}{l}\text { Nail } \\
\text { Biting }\end{array}$} \\
\hline & $\begin{array}{l}\text { Yes } \\
n=193\end{array}$ & $\begin{array}{l}\text { No } \\
n=481\end{array}$ & $\begin{array}{l}\text { Yes } \\
\mathrm{n}=153\end{array}$ & $\begin{array}{l}\text { No } \\
\mathrm{n}=521\end{array}$ & $\begin{array}{l}\text { Yes } \\
n=89\end{array}$ & $\begin{array}{l}\text { No } \\
\mathrm{n}=585\end{array}$ & $\begin{array}{l}\text { Yes } \\
\mathrm{n}=288\end{array}$ & $\begin{array}{l}\text { No } \\
\mathrm{n}=386\end{array}$ & $\begin{array}{l}\text { Yes } \\
n=442\end{array}$ & $\begin{array}{l}\text { No } \\
n=232\end{array}$ \\
\hline Overjet $>4 \mathrm{~mm}$ & 0 & 2 & 1 & 1 & 0 & 2 & 0 & 2 & 2 & 0 \\
\hline Overjet $0-4 \mathrm{~mm}$ & 155 & 418 & 129 & 444 & 81 & 492 & 245 & 328 & 381 & 192 \\
\hline Overjet $<0 \mathrm{~mm}$ & 38 & 61 & 23 & 76 & 8 & 91 & 43 & 56 & 59 & 40 \\
\hline$P$ value & 0.067 & & 0.645 & & 0.222 & & 0.469 & & 0.243 & \\
\hline
\end{tabular}

Table 5. Prevalence of oral habit according to overbite

\begin{tabular}{|c|c|c|c|c|c|c|c|c|c|c|}
\hline \multirow[b]{2}{*}{$\begin{array}{l}\text { Oral habit } \\
\text { Problem }\end{array}$} & \multicolumn{2}{|l|}{$\begin{array}{l}\text { Mouth } \\
\text { breathing }\end{array}$} & \multicolumn{2}{|c|}{$\begin{array}{l}\text { Abnormal } \\
\text { swallowing }\end{array}$} & \multicolumn{2}{|c|}{$\begin{array}{l}\text { Thumb } \\
\text { sucking }\end{array}$} & \multicolumn{2}{|l|}{$\begin{array}{l}\text { Lip } \\
\text { sucking }\end{array}$} & \multicolumn{2}{|l|}{$\begin{array}{l}\text { Nail } \\
\text { biting }\end{array}$} \\
\hline & $\begin{array}{l}\text { Yes } \\
n=193\end{array}$ & $\begin{array}{l}\text { No } \\
\mathrm{n}=481\end{array}$ & $\begin{array}{l}\text { Yes } \\
n=153\end{array}$ & $\begin{array}{l}\text { No } \\
n=521\end{array}$ & $\begin{array}{l}\text { Yes } \\
n=89\end{array}$ & $\begin{array}{l}\text { No } \\
\mathrm{n}=585\end{array}$ & $\begin{array}{l}\text { Yes } \\
\mathrm{n}=288\end{array}$ & $\begin{array}{l}\text { No } \\
\mathrm{n}=386\end{array}$ & $\begin{array}{l}\text { Yes } \\
n=442\end{array}$ & $\begin{array}{l}\text { No } \\
n=232\end{array}$ \\
\hline Overbite $>4 \mathrm{~mm}$ & 1.000 & 2 & 1.000 & 2 & 0.000 & 3 & 1.000 & 2 & 1.000 & 2 \\
\hline Overbite $0-4 \mathrm{~mm}$ & 149.000 & 376 & 120.000 & $40 \overline{5}$ & 72.000 & 453 & 222.000 & 303 & 346.000 & 179 \\
\hline Overbite $<0 \mathrm{~mm}$ & 43.000 & 103 & 32.000 & 114 & 17.000 & 129 & 65.000 & 81 & 95.000 & 51 \\
\hline P value & 0.953 & & 0.882 & & 0.642 & & 0.843 & & 0.491 & \\
\hline
\end{tabular}




\begin{tabular}{|c|c|c|c|c|c|c|c|c|c|c|}
\hline \multirow[b]{2}{*}{$\begin{array}{l}\text { Oral habit } \\
\text { Problem }\end{array}$} & \multicolumn{2}{|c|}{$\begin{array}{l}\text { Mouth } \\
\text { Breathing }\end{array}$} & \multicolumn{2}{|c|}{$\begin{array}{l}\text { Abnormal } \\
\text { Swallowing }\end{array}$} & \multicolumn{2}{|c|}{$\begin{array}{l}\text { Thumb } \\
\text { Sucking }\end{array}$} & \multicolumn{2}{|l|}{$\begin{array}{l}\text { Lip } \\
\text { Sucking }\end{array}$} & \multicolumn{2}{|l|}{$\begin{array}{l}\text { Nail } \\
\text { Biting }\end{array}$} \\
\hline & $\begin{array}{l}\text { Yes } \\
n=193\end{array}$ & $\begin{array}{l}\text { No } \\
\mathrm{n}=481\end{array}$ & $\begin{array}{l}\text { Yes } \\
n=153\end{array}$ & $\begin{array}{l}\text { No } \\
\mathrm{n}=521\end{array}$ & $\begin{array}{l}\text { Yes } \\
n=89\end{array}$ & $\begin{array}{l}\text { No } \\
\mathrm{n}=585\end{array}$ & $\begin{array}{l}\text { Yes } \\
n=288\end{array}$ & $\begin{array}{l}\text { No } \\
\mathrm{n}=386\end{array}$ & $\begin{array}{l}\text { Yes } \\
n=442\end{array}$ & $\begin{array}{l}\text { No } \\
\mathrm{n}=232\end{array}$ \\
\hline$\overline{\text { Cross Bite }}$ & 33.000 & 68 & 29.000 & 72 & 11.000 & 90 & 47.000 & 54 & 68.000 & 33 \\
\hline Non-Cross Bite & 160.000 & 413 & 124.000 & 449 & 78.000 & 495 & 241.000 & 332 & 374.000 & 199 \\
\hline$P$ value & 0.330 & & 0.118 & & 0.456 & & 0.402 & & 0.688 & \\
\hline
\end{tabular}

Table 7. Prevalence of oral habit according to scissor bite

\begin{tabular}{|c|c|c|c|c|c|c|c|c|c|c|}
\hline \multirow[b]{2}{*}{$\begin{array}{l}\text { Oral habit } \\
\text { Problem }\end{array}$} & \multicolumn{2}{|l|}{$\begin{array}{l}\text { Mouth } \\
\text { breathing }\end{array}$} & \multicolumn{2}{|c|}{$\begin{array}{l}\text { Abnormal } \\
\text { swallowing }\end{array}$} & \multicolumn{2}{|l|}{$\begin{array}{l}\text { Thumb } \\
\text { sucking }\end{array}$} & \multicolumn{2}{|l|}{$\begin{array}{l}\text { Lip } \\
\text { sucking }\end{array}$} & \multicolumn{2}{|l|}{$\begin{array}{l}\text { Nail } \\
\text { biting }\end{array}$} \\
\hline & $\begin{array}{l}\text { Yes } \\
n=193\end{array}$ & $\begin{array}{l}\text { No } \\
\mathrm{n}=481\end{array}$ & $\begin{array}{l}\text { Yes } \\
n=153\end{array}$ & $\begin{array}{l}\text { No } \\
\mathrm{n}=521\end{array}$ & $\begin{array}{l}\text { Yes } \\
\mathrm{n}=89\end{array}$ & $\begin{array}{l}\text { No } \\
\mathrm{n}=585\end{array}$ & $\begin{array}{l}\text { Yes } \\
n=288\end{array}$ & $\begin{array}{l}\text { No } \\
\mathrm{n}=386\end{array}$ & $\begin{array}{l}\text { Yes } \\
\mathrm{n}=442\end{array}$ & $\begin{array}{l}\text { No } \\
n=232\end{array}$ \\
\hline Scissor bite & 6.000 & 12 & 3.000 & 15 & 2.000 & 16 & 9.000 & 9 & 11.000 & 7 \\
\hline Non-Scissor bite & 187.000 & 469 & 150.000 & 506 & 87.000 & 569 & 279.000 & 377 & 431.000 & 225 \\
\hline $\mathrm{P}$ value & 0.655 & & 0.536 & & 0.790 & & 0.527 & & 0.686 & \\
\hline
\end{tabular}

Table 8. Distribution of malocclusions according to the presence of deleterious oral habits

\begin{tabular}{|c|c|c|c|c|c|}
\hline \multirow[b]{3}{*}{ Type of malocclusion } & \multicolumn{5}{|c|}{ Oral habit } \\
\hline & \multicolumn{2}{|c|}{ Present } & \multicolumn{3}{|c|}{ Absent } \\
\hline & $\mathrm{N}$ & $\%$ & $\mathrm{~N}$ & $\%$ & P-Value \\
\hline CL I Malocclusion & 360 & 53.4 & 55 & 8.1 & 0.001 \\
\hline CL II Malocclusion & 208 & 30.9 & 29 & 4.3 & 0.001 \\
\hline CL III Malocclusion & 21 & 3.1 & 1 & 0.1 & 0.001 \\
\hline Overjet $>4 \mathrm{~mm}$ & 89 & 13.2 & 10 & 1.5 & 0.001 \\
\hline Overjet $0-4 \mathrm{~mm}$ & 498 & 73.9 & 75 & 11.1 & 0.001 \\
\hline Overjet $<0 \mathrm{~mm}$ & 2 & 0.3 & 0 & 0.0 & - \\
\hline Overbite $>4 \mathrm{~mm}$ & 125 & 18.9 & 21 & 3.1 & 0.001 \\
\hline Overbite $0-4 \mathrm{~mm}$ & 462 & 68.5 & 63 & 9.3 & 0.001 \\
\hline Overbite $<0 \mathrm{~mm}$ & 2 & 0.3 & 1 & 0.1 & - \\
\hline Cross Bite & 92 & 13.6 & 9 & 1.3 & 0.001 \\
\hline Non-Cross Bite & 497 & 73.7 & 76 & 11.3 & 0.001 \\
\hline Scissor Bite & 15 & 2.2 & 3 & 0.5 & 0.008 \\
\hline Non-Scissor Bite & 584 & 86.6 & 72 & 10.7 & 0.001 \\
\hline
\end{tabular}

\section{Discussion}

Oral habits such as mouth breathing, abnormal swallowing, thumb sucking, lip sucking and nail biting can have direct influence onquality of life and can affect the stomatognathic system of the body (Agarwal et al., 2014). The present study represents an epidemiological survey carried out on an Italian population (Table 8). This study showed that significant relationships existed between deleterious oral habits and malocclusions. In a similar study, (Aznar et al., 2006) evaluated the relationship between arch width and certain oral habits in 3 to 6 year-old children and found that a dummy habit leads to a reduction in maxillary arch width and mouth breathing causes a reduction in the size of both arches.

Cavalcanti et al. (2008) studied the associations between malocclusions and deleterious oral habits in preschool children in Brazil and found a high prevalence of malocclusions in a pediatric population under the age of 5 and a positive association with deleterious oral habits.
In the current study the total prevalence rate for oral habits was found to be $84.7 \%$. This amount is similar and comparable to other studies. Hebling et al. (2008) conducted an epidemiological study in a sample of 5-year-old children attending preschools and reported that deleterious oral habits were observed in $83.1 \%$ of the children.

In this study, the highest prevalence of deleterious oral habit was for nail biting, which was common in more than $65 \%$ of the subjects and the lowest prevalence was for thumb sucking which was common in only $13 \%$ of the subjects. The habit of mouth breathing was seen among $28.6 \%$ of study population and the results were significantly higher when compared to the findings of the study done by Garde et al. (2014) in among 6 to 12 year old children who found the habit in only $4.3 \%$ of their population. This huge difference might lie in the difference between the methodologies of the researches and the fact that in the current study even subject with mixed mouth and nasal breathing were considered as 
mouth breathers. The same huge difference between the two studies apply for nail biting which was a surprisingly lower amount of $5.8 \%$ in the study conducted by Garde et al. (2014).

Epidemiological surveys assist in recognizing the oral health conditions of different populations, which is essential for taking preventive/interceptive measurements (Perillo et al., 2011a; 2011b; Showkatbakhsh et al., 2013).

This study thus confirms other authors' earlier findings, i.e., various oral habits encourage the development of impaired occlusion of the deciduous dentition and this is more marked when the habit persists for longer than 3 years.

\section{Conclusion}

Positive association exists between deleterious oral habits and malocclusions; however, there is no significant relationship between the type of oral habit and malocclusions.

\section{Author's Contributions}

Letizia Perillo and Abdolreza Jamilian were responsible for study concept, study design, administration, recruitment, drafting, statistical analysis, critical revision and final approval of the article. Davide Giugliano, Fabrizia d'Apuzzo were responsible for recruitment of participants, obtaining ethical approval, data collection and data interpretation.

\section{References}

Agarwal, S.S., K. Nehra, M. Sharma, B. Jayan and A. Poonia et al., 2014. Association between breastfeeding duration, non-nutritive sucking habits and dental arch dimensions in deciduous dentition: A cross-sectional study. Progress Orthodontics. DOI: 10.1186/s40510-014-0059-4

Aznar, T., A.F. Galan, I. Marin and A. Dominguez, 2006. Dental arch diameters and relationships to oral habits. Angle Orthodontist, 76: 441-445. PMID: 16637724

Cavalcanti, L.A., M.K.P. Bezerra, C. Moura, M.P. Bezerra and F.A. Granville-Gracia, 2008. Relationship between malocclusion and deleterious oral habits in preschool children in campina grande, pb, brazil. Stomatološki Glasnik Srbije, 55: 154-162. DOI: 10.2298/SGS0803154C

Garde, J.B., R.K. Suryavanshi, B.A. Jawale, V. Deshmukh and D.P. Dadhe et al., 2014. An epidemiological study to know the prevalence of deleterious oral habits among 6 to 12 year old children. J. Int. Oral Health, 6: 39-43. PMID: 3959135
Hebling, S.R., K.L. Cortellazzi, E.P. Tagliaferro, E. Hebling and G.M. Ambrosano et al., 2008. Relationship between malocclusion and behavioral, demographic and socioeconomic variables: A cross-sectional study of 5-year-olds. J. Clinical Pediatric Dent., 33: 75-79. PMID: 19093656

Jamilian, A., M. Toliat and S. Etezad, 2010. Prevalence of malocclusion and index of orthodontic treatment need in children in Tehran. Oral Health Preventive Dent., 8: 339-343. PMID: 21180670

Lagana, G., C. Masucci, F. Fabi, P. Bollero and P. Cozza, 2013. Prevalence of malocclusions, oral habits and orthodontic treatment need in a 7- to 15-year-old schoolchildren population in Tirana. Progress Orthodontics. DOI: 10.1186/2196-1042-14-12

Liu, Z., C. McGrath and U. Hagg, 2009. The impact of malocclusion/orthodontic treatment need on the quality of life. A systematic review. Angle Orthodontist, 79: 585-591. DOI: 10.2319/042108-224.1

Luzzi, V., M. Guaragna, G. Ierardo, M. Saccucci and G. Consoli et al., 2011. Malocclusions and nonnutritive sucking habits: A preliminary study. Progress Orthodontics, 12: 114-118. DOI: $10.1016 /$ j.pio.2011.03.002

Melsen, B., L. Attina, M. Santuari and A. Attina, 1987. Relationships between swallowing pattern, mode of respiration and development of malocclusion. Angle Orthodontist, 57: 113-120. PMID: 3473947

Perillo, L., C. Masucci, F. Ferro, D. Apicella and T. Baccetti, 2010. Prevalence of orthodontic treatment need in southern Italian schoolchildren. Eur. J. Orthodontics, 32: 49-53. DOI: 10.1093/ejo/cjp050

Perillo, L., M.I. Castaldo, R. Cannavale, A. Longobardi and V. Grassia et al., 2011a. Evaluation of long-term effects in patients treated with Fränkel-2 appliance. Eur. J. Paediatr. Dent., 12: 261-266. PMID: 22185253

Perillo, L., B. Femminella, D. Farronato, T. Baccetti and L. Contardo et al., 2011b. Do malocclusion and Helkimo Index $\geq 5$ correlate with body posture? J. Oral Rehabilitation, 38: 242-252. DOI: $10.1111 / \mathrm{j} .1365-2842.2010 .02156 . \mathrm{x}$

Showkatbakhsh, R., M.I. Castaldo, A. Jamilian, G. Padricelli and M. Fahimi et al., 2013. Treatment effects of r-appliance and frankel-2 in class ii division 1 malocclusions. Eur. J. Paediatr. Dent., 14: 17-22. PMID: 23597214

Souames, M., F. Bassigny, N. Zenati, P.J. Riordan and M.L. Boy-Lefevre, 2006. Orthodontic treatment need in french schoolchildren: An epidemiological study using the index of orthodontic treatment need. Eur. J. Orthodontics, 28: 605-609. DOI: 10.1093/ejo/cj1045 